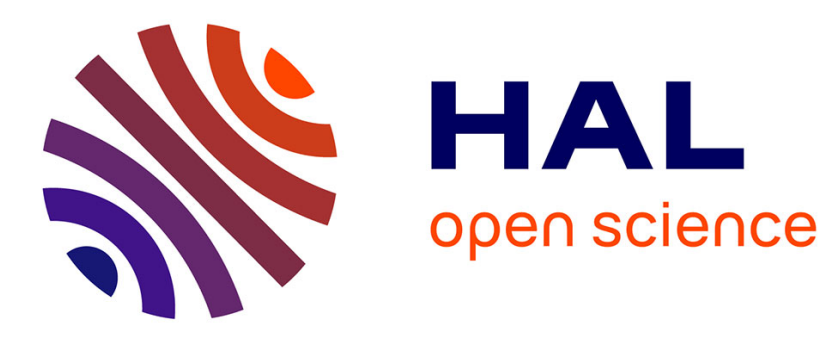

\title{
Synthesis and switching properties of new derivatives of azoresveratrol
}

Jérôme Berthet, Laurence Agouridas, Siyao Chen, Hassan Allouchi, Patricia Melnyk, Benoît Champagne, Stéphanie Delbaere

\section{To cite this version:}

Jérôme Berthet, Laurence Agouridas, Siyao Chen, Hassan Allouchi, Patricia Melnyk, et al.. Synthesis and switching properties of new derivatives of azoresveratrol. Dyes and Pigments, 2019, 171, pp.107666 -. 10.1016/j.dyepig.2019.107666 . hal-03484526

\section{HAL Id: hal-03484526 \\ https://hal.science/hal-03484526}

Submitted on 20 Dec 2021

HAL is a multi-disciplinary open access archive for the deposit and dissemination of scientific research documents, whether they are published or not. The documents may come from teaching and research institutions in France or abroad, or from public or private research centers.
L'archive ouverte pluridisciplinaire HAL, est destinée au dépôt et à la diffusion de documents scientifiques de niveau recherche, publiés ou non, émanant des établissements d'enseignement et de recherche français ou étrangers, des laboratoires publics ou privés.

\section{다)(1) $(5$}

Distributed under a Creative Commons Attribution - NonCommercial| 4.0 International 


\section{Synthesis and switching properties of new derivatives of azoresveratrol}

Jérôme Berthet, ${ }^{1}$ Laurence Agouridas, ${ }^{2}$ Siyao Chen, ${ }^{2}$ Hassan Allouchi, ${ }^{3}$ Patricia Melnyk, ${ }^{2}$ Benoît Champagne, ${ }^{4}$ Stéphanie Delbaere ${ }^{1, *}$

1. Univ. Lille, CNRS, UMR 8516 - LASIR - Laboratoire de Spectrochimie Infra-rouge et Raman, F-59000 Lille, France

2. Univ. Lille, Inserm, CHU Lille, UMR-S 1172 - JPArc - Centre de Recherche Jean-Pierre Aubert Neurosciences et Cancer, F-59000 Lille, France

3. Univ. de Tours, EA 7502 SIMBA - Laboratoire de Chimie Physique, Faculté de Pharmacie, 31, avenue Monge, F-37200 Tours, France

4. Laboratory of Theoretical Chemistry, Theoretical and Structural Physical Chemistry Unit, Namur Institute of Structured Matter, University of Namur, rue de Bruxelles, 61, B-5000 Namur, Belgium.

*Corresponding author : stephanie.delbaere@univ-lille.fr

Abstract. The synthesis and response upon light irradiation of azoresveratrol and six derivatives are reported. While UV irradiation of para-hydroxy trans compounds leads to thermally unstable cis isomers, the para-methoxy and the para-phosphoric ester substituents result in reaching a high conversion and increasing the thermal stability. In addition, the phosphoric ester azo derivative presents similar properties in organic and aqueous solutions, opening the way towards biological applications.

Keywords. Azobenzene, Photoswitching, Thermal relaxation, UV irradiation, NMR, DFT calculations. 


\section{Graphical abstract}

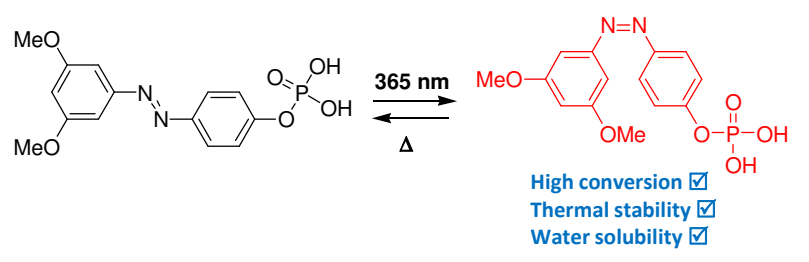

\section{Introduction}

Photoswitchable molecules have been extensively investigated over the past few years due to their potential in technological advanced applications ranging from molecular electronics [1] to biology [2]. These applications rely on the reversible interconversion, being induced by light at least in one direction, between two (meta)stable states which have different properties. In the area of electronic devices such as switches, transistors and logic gates, diarylethenes represent one of the most widely synthesized and studied (P-type) molecular switches nowadays. They are based on cyclization/opening reactions induced by UV/visible illumination. In the field of photopharmacology, photoswitches are of particular interest, especially the reversible trans-cis photoisomerization of azobenzenes. Indeed, light induces changes in the molecular length and polarity of the azobenzenes, which have multiple positive biological advantages [3-4]. At equilibrium in the dark, azobenzenes exist in the more stable trans conformation. Irradiation with UV light produces a large fraction of the cis isomer, which can revert back to the trans state thermally (T-type) or upon irradiation with visible light [5]. The thermal cis-to-trans isomerization of azobenzenes has attracted much attention, being the subject of many theoretical and experimental investigations [6-9], with a relaxation rate highly depending on the 
number, the nature and the position of substituents in the phenyl groups decorating the azo bond [10-14].

Similarly to various polyphenols, resveratrol [15] (3,5,4'-trihydroxy-trans-stilbene, scheme 1$)$ has been reported to play a major role in the formation or disaggregation of fibrils or amyloid, proteic species implied in many neurodegenerative diseases. Despite its poor bioavailability, it exhibits multiple positive biological activities, mainly anti-oxidizing, anti-inflammatory and neuroprotective capacities [16-17]. Resveratrol can be photochemically isomerized between the trans and cis isomers, but the cyclization/oxidation of it into the phenanthrenic derivative byproduct [18] impedes its biological photo-application. We therefore aimed at boosting resveratrol promising properties in the field of photopharmacology applied to neurodegenerative diseases using photoswitchable azoresveratrol derivatives by exploring the effect of electron-donating group in azobenzenes substituted in the para position with hydroxy, alkoxy and phosphoric ester groups. Here, we report on the synthesis of very simple molecular structures and on their photoresponse upon light irradiation and on their thermal relaxation investigated by UV/visible and NMR spectroscopies.

\section{Results and Discussion}

\subsection{Synthesis}

Azoresveratrol 1 and its derivative 2 were prepared as described in the literature [19-21]. Methylation of $\mathbf{2}$ in the presence of methyl iodide [22] afforded the fully protected azoresveratrol derivative $\mathbf{4}$ whereas the phosphoric ester derivative $\mathbf{5}$ was obtained from reaction of $\mathbf{2}$ with phosphoryl chloride in the presence of triethylamine [23]. Ortho-substituted 
azoresveratrol compounds $\mathbf{3}, \mathbf{6}$ and $\mathbf{7}$ were prepared according to a similar procedure [21] via diazotization of aniline derivatives using sodium nitrite followed by in situ addition of phenol derivatives (Scheme 1).

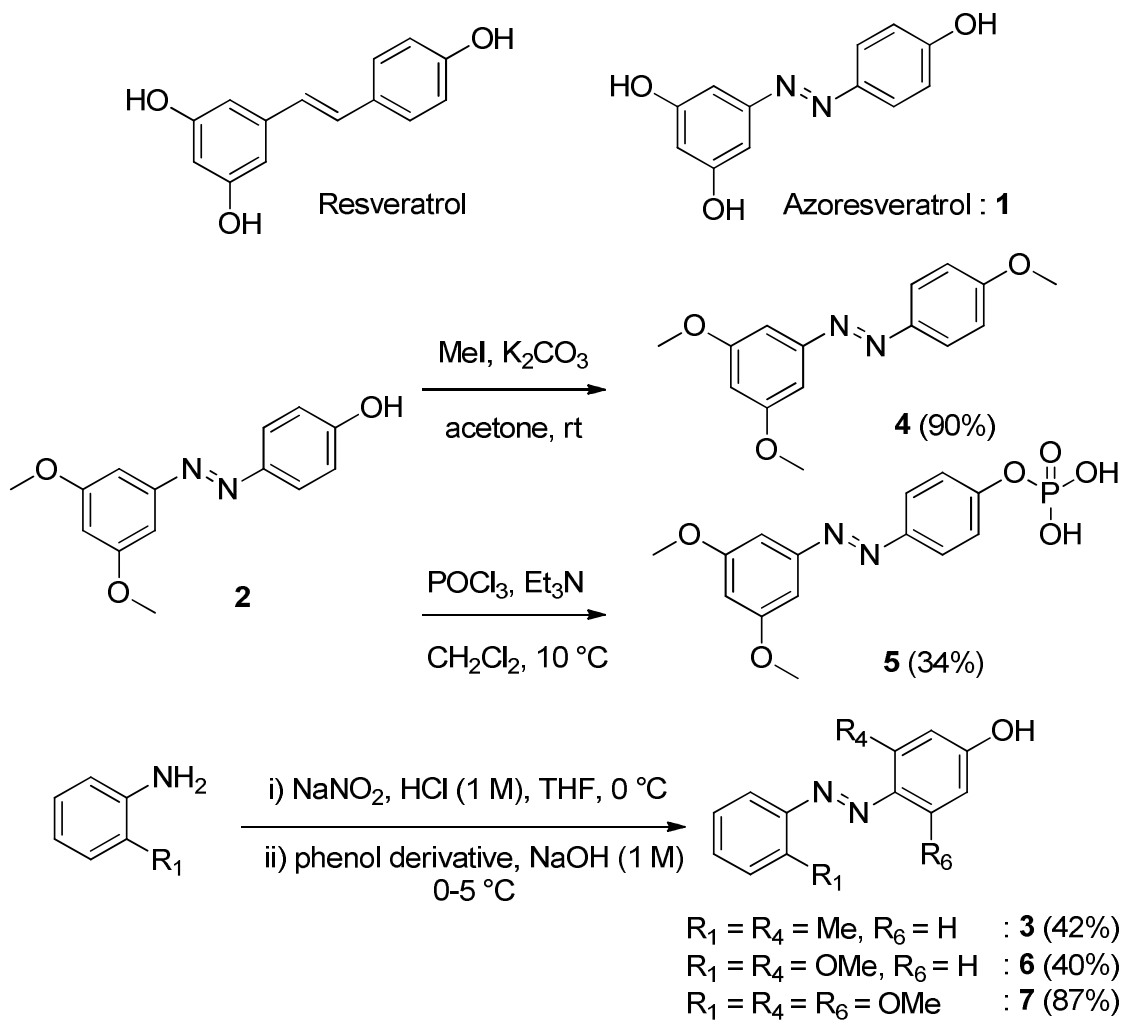

Scheme 1. Chemical structures of resveratrol and 1-7 and synthetic routes.

\subsection{Spectroscopic characterization of 1-7}

The spectral properties of the seven synthesized azo derivatives were investigated by UV/visible spectroscopy, correlated with their structures by NMR spectroscopy. Compounds 1-5 exhibited a strong band peaking between 300 and $400 \mathrm{~nm}$, with a maximum ranging from 348 to $354 \mathrm{~nm}$ (allowed $\pi-\pi^{*}$ transition of the trans isomer) associated with a molar absorption coefficient $\varepsilon$ between 2.1 and $2.7 \times 10^{4} \mathrm{~L} \mathrm{~mol}^{-1} \mathrm{~cm}^{-1}$, and a weaker broad band around $460 \mathrm{~nm}$ (forbidden $n-\pi^{*}$ transition) (Figure 1). The replacement of the ethylenic bond in resveratrol with 
an azo junction bathochromically shifted the absorption band associated with a small increase of the $\varepsilon$ values. By contrast, compound 6 absorbed at $377 \mathrm{~nm}\left(\varepsilon=1.9 \times 10^{4} \mathrm{~L} \mathrm{~mol}^{-1} \mathrm{~cm}^{-1}\right)$ with a shoulder at $450 \mathrm{~nm}\left(\varepsilon=0.8 \times 10^{4} \mathrm{~L} \mathrm{~mol}^{-1} \mathrm{~cm}^{-1}\right)$ while 7 displayed a broad and higher absorption band at $425 \mathrm{~nm}\left(\varepsilon=4.5 \times 10^{4} \mathrm{~L} \mathrm{~mol}^{-1} \mathrm{~cm}^{-1}\right)$.

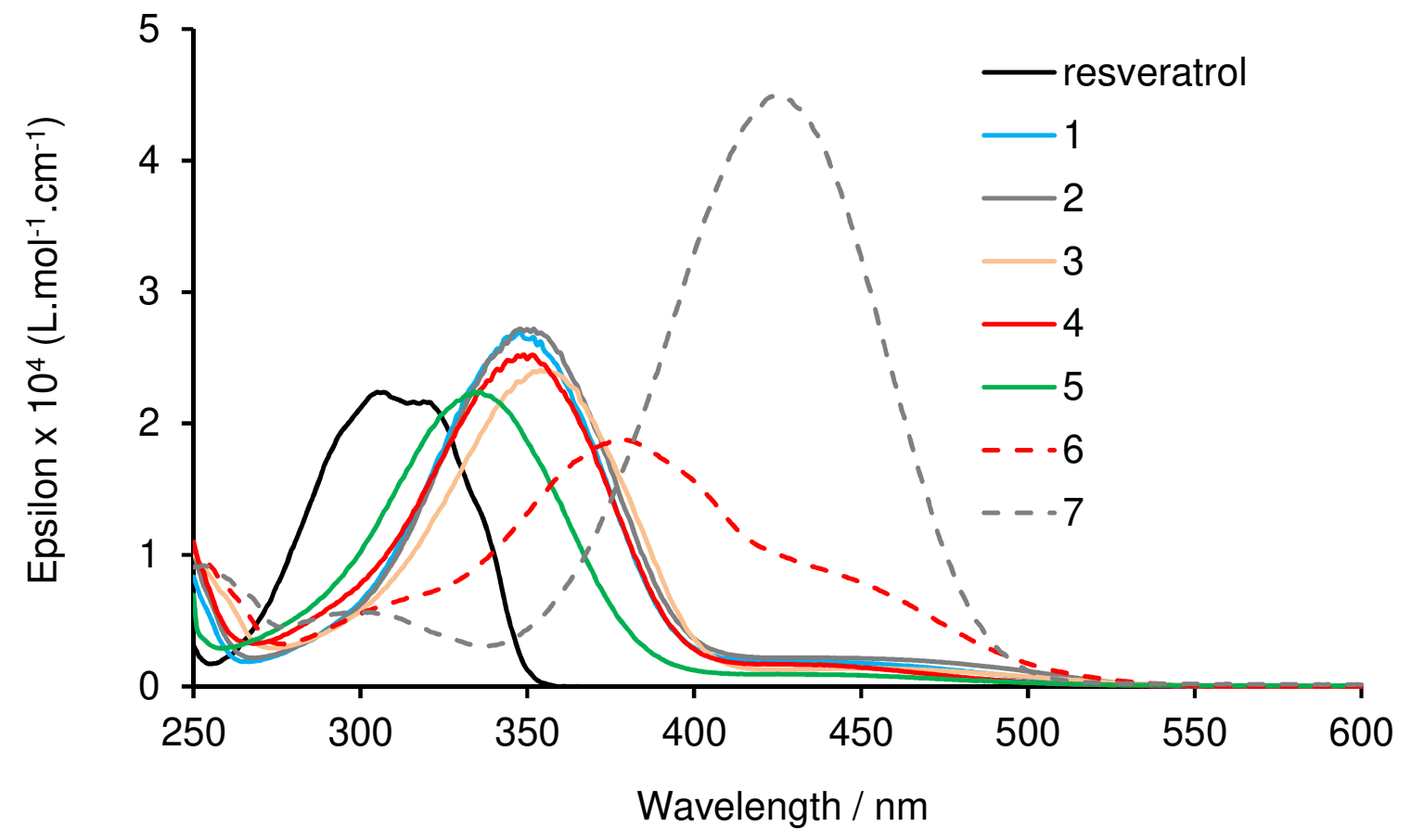

Figure 1. UV/visible absorption spectra of resveratrol and azo derivatives 1-7 in acetonitrile.

NMR spectroscopy (Figure 2) clearly indicated that 1-5 were under their trans azo configuration and 7 was proved to be the tautomeric quinone-phenylhydrazone derivative with more particularly the signature of the $-\mathrm{C}=\mathrm{O}$ resonance at $187.2 \mathrm{ppm}$ in ${ }^{13} \mathrm{C}$ NMR spectrum (Figures S2S5). In fact, in all solvents used, chloroform, methanol and acetonitrile, 7 presents always the same spectrum, indicating that the tautomeric equilibrium expected for arylazo-phenol compounds [24] is completely shifted towards the hydrazone form, whereas totally shifted 
towards the azo form for 1-5. As for 6, it exists as a tautomeric equilibrium mixture in acetonitrile and methanol (95:5 and $88: 12$ azo:hydrazone, respectively), but is $100 \%$ in the hydrazone form in chloroform (Figures S7-S9).
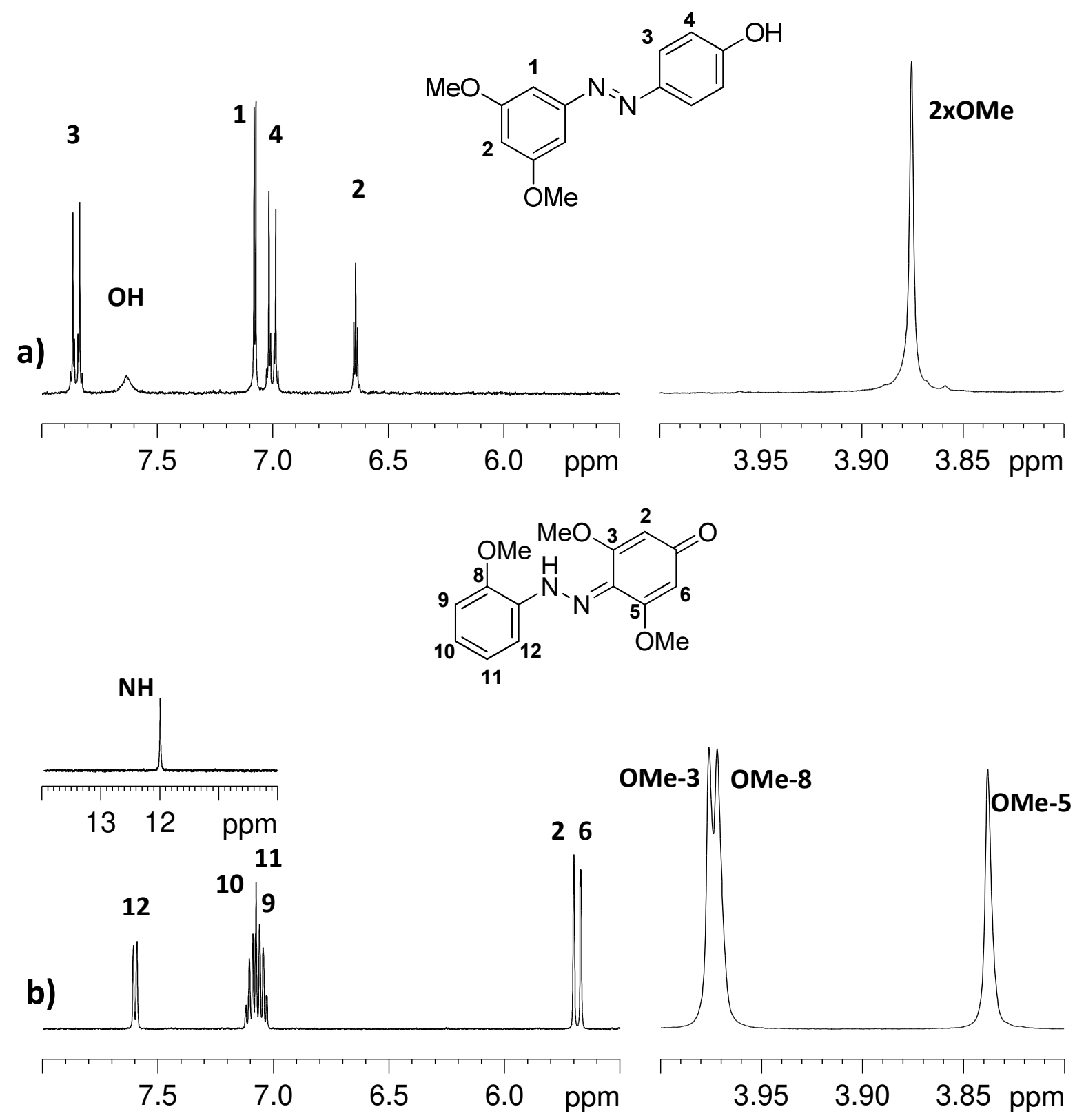

Figure $2 .{ }^{1} \mathrm{H}$ NMR spectra of the a) azo derivative $\mathbf{2}$ and b) quinone-phenylhydrazone derivative $\mathbf{7}$ in $\mathrm{CD}_{3} \mathrm{CN}$. 


\subsection{Switching properties investigated by UV/visible and NMR spectroscopy}

All the compounds (resveratrol and the seven azo derivatives in acetonitrile) were submitted to irradiation to induce the photoisomerization trans $\rightarrow$ cis, then the thermal evolution of the samples was recorded. UV/visible and NMR spectroscopy were used to run the transformations. Irradiation with $313 \mathrm{~nm}$ light at $22{ }^{\circ} \mathrm{C}$ of resveratrol led to the formation of the cis isomer, followed by cyclization/oxidation into the phenanthrenic derivative by-product (Figures S10-13), as already reported in the literature [18]. Irradiation with $365 \mathrm{~nm}$ light at $22{ }^{\circ} \mathrm{C}$ was then applied to the azo derivatives 1-5. Only changes in the spectra of $\mathbf{4}$ and $\mathbf{5}$ could be observed, with the hypsochromic shift and decrease of the main UV/visible band $\left(\lambda_{\max }=304\right.$ and $289 \mathrm{~nm}$ for 4 (Figure S24) and 5 (Figure S29), respectively) whereas the intensity of the lower band at 436 and $432 \mathrm{~nm}$ for 4 and 5, respectively was increased. By NMR spectroscopy, new resonances were detected while the signals of the initial trans isomer decreased in intensity (Figures S25 and S31). No spectral variation was evidenced at $22{ }^{\circ} \mathrm{C}$ for $\mathbf{1 - 3}$, because of a very short life time of photoproducts. Then, experiments on these three hydroxy derivatives were repeated at $-45^{\circ} \mathrm{C}$. Irradiation with $365 \mathrm{~nm}$ light at low temperature converted the initial trans state of 1-3 into a new photoproduct as evidenced with the appearance of a set of new signals in ${ }^{1} \mathrm{H}$ spectra (Figures 3, S18, S22). 
<smiles>Oc1ccc(N=Nc2cc(O)cc(O)c2)cc1</smiles>

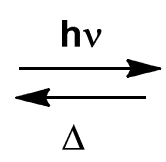<smiles>Oc1ccc(/N=N\c2ccc(O)cc2)cc1</smiles>
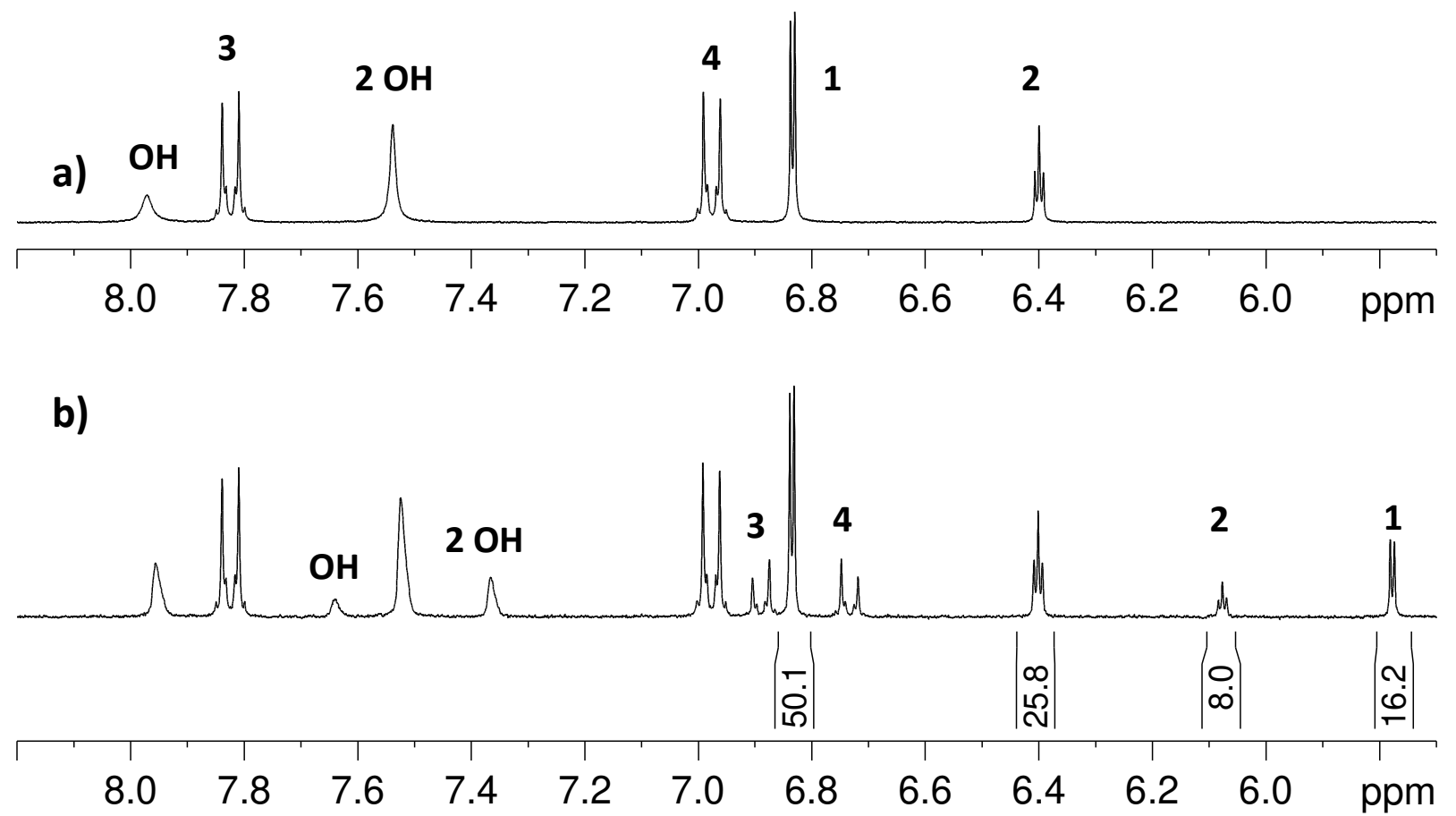

Figure $3 .{ }^{1} \mathrm{H}$ NMR spectra of 1 in acetonitrile- $\mathrm{d}_{3}$ at $-45^{\circ} \mathrm{C}$ a) before and b) after irradiation with $365 \mathrm{~nm}$ light (PSS).

The photoproducts generated at $22{ }^{\circ} \mathrm{C}$ from 4 and 5 and at $-45^{\circ} \mathrm{C}$ from $1-3$ were unambiguously identified as their cis isomers. The cis configuration of the $-\mathrm{N}=\mathrm{N}-$ double bond was nicely evidenced by ${ }^{1} \mathrm{H}-{ }^{1} \mathrm{H}$ NMR dipolar correlations (Figure S28) between protons located in each benzene ring and by a shielding of all signals. This is in total agreement with a structure where both phenyl groups are in close spatial interactions, leading to lower values of the chemical shifts by the shielding effect of the aromatic rings. Finally, for the two derivatives 6 and 7, no 
change was detected upon irradiation using whatever the solvent (acetonitrile, chloroform, methanol), the temperature $\left(22^{\circ} \mathrm{C},-45^{\circ} \mathrm{C},-80^{\circ} \mathrm{C}\right)$ and the wavelength of the irradiation light $(365,436 \mathrm{~nm})$.

When the photostationary state (PSS, Table 1) was reached, the thermal evolution of samples was followed by recording ${ }^{1} \mathrm{H}$ NMR spectra at regular time intervals. By measuring the peakintensities of signals for the trans and cis isomers, the time-evolution of concentrations at $-45^{\circ} \mathrm{C}$ for 1, 2 and 3 (Figures S16, S19, S23) and at $22^{\circ} \mathrm{C}$ for $\mathbf{4}$ and $\mathbf{5}$ (Figures S26 and S32) was plotted. With the exception of the compound 5, the thermal decay of all cis isomers was monoexponential ( $k_{\Delta}$, Table 1$)$. In contrast, the thermal relaxation of the cis isomer of $\mathbf{5}$ followed a biexponential decay. Solvent effects can be suggested to explain such a behavior. As the derivative $\mathbf{5}$ is soluble in water, experiments of photoisomerization and thermal relaxation were repeated in $\mathrm{D}_{2} \mathrm{O}$ (at $2.5 \mathrm{mM}, \mathrm{T}=22^{\circ} \mathrm{C}$ ), where $\mathrm{pH}$ was determined to be equal to 2 . Irradiation with $365 \mathrm{~nm}$ light led to the formation of $70 \%$ of the cis isomer of $\mathbf{5}$ in $\mathrm{D}_{2} \mathrm{O}$ at PSS (Figure 4), which followed again a bi-exponential evolution in the dark, although accelerated (Figure S34). An additional assay was then performed in $\mathrm{D}_{2} \mathrm{O}$ where $\mathrm{pH}$ was adjusted at 8 by adding $\mathrm{NaOD}$. About $94 \%$ of the cis isomer was produced at PSS (Figure S35). In contrast, its thermal stability at $22{ }^{\circ} \mathrm{C}$ was so high that no significant evolution could be observed. 
Table 1. Ratio at photostationary state between the cis and trans isomers, PSS (cis:trans), rate constants of relaxation, $\mathrm{k}_{\Delta}$ with experimental temperature $(\mathrm{T})$; time to convert $50 \%$ of the cis isomer into the trans isomer, $\mathrm{t}_{1 / 2}$, for the derivatives 1-5 with experimental conditions (Solvent).

\begin{tabular}{|c|c|c|c|c|}
\hline & Solvent & $\begin{array}{c}\text { PSS } \\
\text { (cis:trans) }\end{array}$ & $k_{\Delta}(T)$ & $t_{1 / 2}$ \\
\hline & $\mathrm{CD}_{3} \mathrm{CN}$ & $24: 76$ & $4.1 \times 10^{-3} \mathrm{~s}^{-1}\left(-45^{\circ} \mathrm{C}\right)$ & $2.8 \min \left(-45^{\circ} \mathrm{C}\right)$ \\
\hline & $\mathrm{CD}_{3} \mathrm{CN}$ & $25: 75$ & $3.0 \times 10^{-3} \mathrm{~s}^{-1}\left(-45^{\circ} \mathrm{C}\right)$ & $3.9 \min \left(-45^{\circ} \mathrm{C}\right)$ \\
\hline & $\mathrm{CD}_{3} \mathrm{CN}$ & $64: 36$ & $1.4 \times 10^{-4} \mathrm{~s}^{-1}\left(-45^{\circ} \mathrm{C}\right)$ & $82 \min \left(-45^{\circ} \mathrm{C}\right)$ \\
\hline & $\begin{array}{c}\mathrm{CD}_{3} \mathrm{CN} \\
\mathrm{CD}_{3} \mathrm{CN}+\mathrm{PPA}\end{array}$ & $\begin{array}{l}83: 17 \\
87: 13\end{array}$ & $\begin{array}{l}5.5 \times 10^{-6} \mathrm{~s}^{-1}\left(22^{\circ} \mathrm{C}\right) \\
\mathrm{k}=3.5 \times 10^{-5} \mathrm{~s}^{-1} \text { and } \mathrm{k}^{\prime}=1.8 \times 10^{-4} \mathrm{~s}^{-1}\left(22^{\circ} \mathrm{C}\right)\end{array}$ & $\begin{array}{l}34.9 \mathrm{~h}\left(22^{\circ} \mathrm{C}\right) \\
1.8 \mathrm{~h}\left(22^{\circ} \mathrm{C}\right)\end{array}$ \\
\hline 5 & $\begin{array}{c}\mathrm{CD}_{3} \mathrm{CN} \\
\mathrm{D}_{2} \mathrm{O}(\mathrm{pH}=2) \\
\mathrm{D}_{2} \mathrm{O}(\mathrm{pH}=8) \\
\mathrm{D}_{2} \mathrm{O}(\mathrm{pH}=8) \\
\mathrm{D}_{2} \mathrm{O}(\mathrm{pH}=8) \\
\mathrm{D}_{2} \mathrm{O}(\mathrm{pH}=8)\end{array}$ & $\begin{array}{l}90: 10 \\
70: 30 \\
94: 06 \\
89: 11 \\
88: 12 \\
82: 18\end{array}$ & $\begin{array}{l}\mathrm{k}=1.8 \times 10^{-5} \mathrm{~s}^{-1} \text { and } \mathrm{k}^{\prime}=1.2 \times 10^{-4} \mathrm{~s}^{-1}\left(22^{\circ} \mathrm{C}\right) \\
\mathrm{k}=4.0 \times 10^{-5} \mathrm{~s}^{-1} \text { and } \mathrm{k}^{\prime}=3.4 \times 10^{-4} \mathrm{~s}^{-1}\left(22^{\circ} \mathrm{C}\right) \\
\text { No significant evolution }\left(22^{\circ} \mathrm{C}\right) \\
3.4 \times 10^{-6} \mathrm{~s}^{-1}\left(30^{\circ} \mathrm{C}\right) \\
1.3 \times 10^{-5} \mathrm{~s}^{-1}\left(40^{\circ} \mathrm{C}\right) \\
2.4 \times 10^{-5} \mathrm{~s}^{-1}\left(45^{\circ} \mathrm{C}\right)\end{array}$ & $\begin{array}{l}4 \mathrm{~h}\left(22^{\circ} \mathrm{C}\right) \\
1.7 \mathrm{~h}\left(22^{\circ} \mathrm{C}\right) \\
-- \\
2.3 \mathrm{~d}\left(30^{\circ} \mathrm{C}\right) \\
15 \mathrm{~h}\left(40^{\circ} \mathrm{C}\right) \\
8.2 \mathrm{~h}\left(45^{\circ} \mathrm{C}\right)\end{array}$ \\
\hline
\end{tabular}

To induce the back cis $\rightarrow$ trans isomerization of the derivative 5 in $\mathrm{D}_{2} \mathrm{O}$, light and temperature effects were studied. Upon visible light irradiation ( $436 \mathrm{~nm})$, the reversion from cis to trans was not fully accomplished, but an equilibrium of cis-trans (25\%-75\% at $\mathrm{pH}=2$ (Figure S33c) and 39 \%-61 \% at $\mathrm{pH}=8$ (Figure S35c)) was reached due to both isomers absorbing $436 \mathrm{~nm}$ light. A very good reproducibility was observed when the derivative 5 in $\mathrm{D}_{2} \mathrm{O}$ at $\mathrm{pH}=8$ was submitted to successive cycles of irradiation with $365 \mathrm{~nm}$ then $436 \mathrm{~nm}$ light, showing then excellent cycling performance (Figure S36). When the relaxation temperature of the sample in $\mathrm{D}_{2} \mathrm{O}$ at $\mathrm{pH}=8$ was raised at 30,40 and $45{ }^{\circ} \mathrm{C}$, the thermal isomerization from cis to trans became efficient and 
followed a mono-exponential decay, with half-life times from 2.3 days to 8 hours in the range of the investigated temperatures (Figures S37-S39). From the Eyring plots $\ln \left(\mathrm{k}_{\Delta} / \mathrm{T}\right) \mathrm{vs} .1 / \mathrm{T}$, the standard entropy and enthalpy of activation, $\Delta \mathrm{S}^{\#}=-17.9 \mathrm{~J} \mathrm{~mol}^{-1} \mathrm{~K}^{-1}$ and $\Delta \mathrm{H}^{\#}=100.6 \mathrm{~kJ} \mathrm{~mol}^{-1}$ were deduced (Figure S40), in agreement with the energy barrier for the azobenzene thermal isomerization $[10,25]$.<smiles>COc1cc(N=Nc2ccc(OC)c(O)c2)cc(OC)c1</smiles>

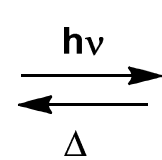<smiles>COc1ccc(/N=N\c2cc(OC)cc(OC)c2)cc1</smiles>
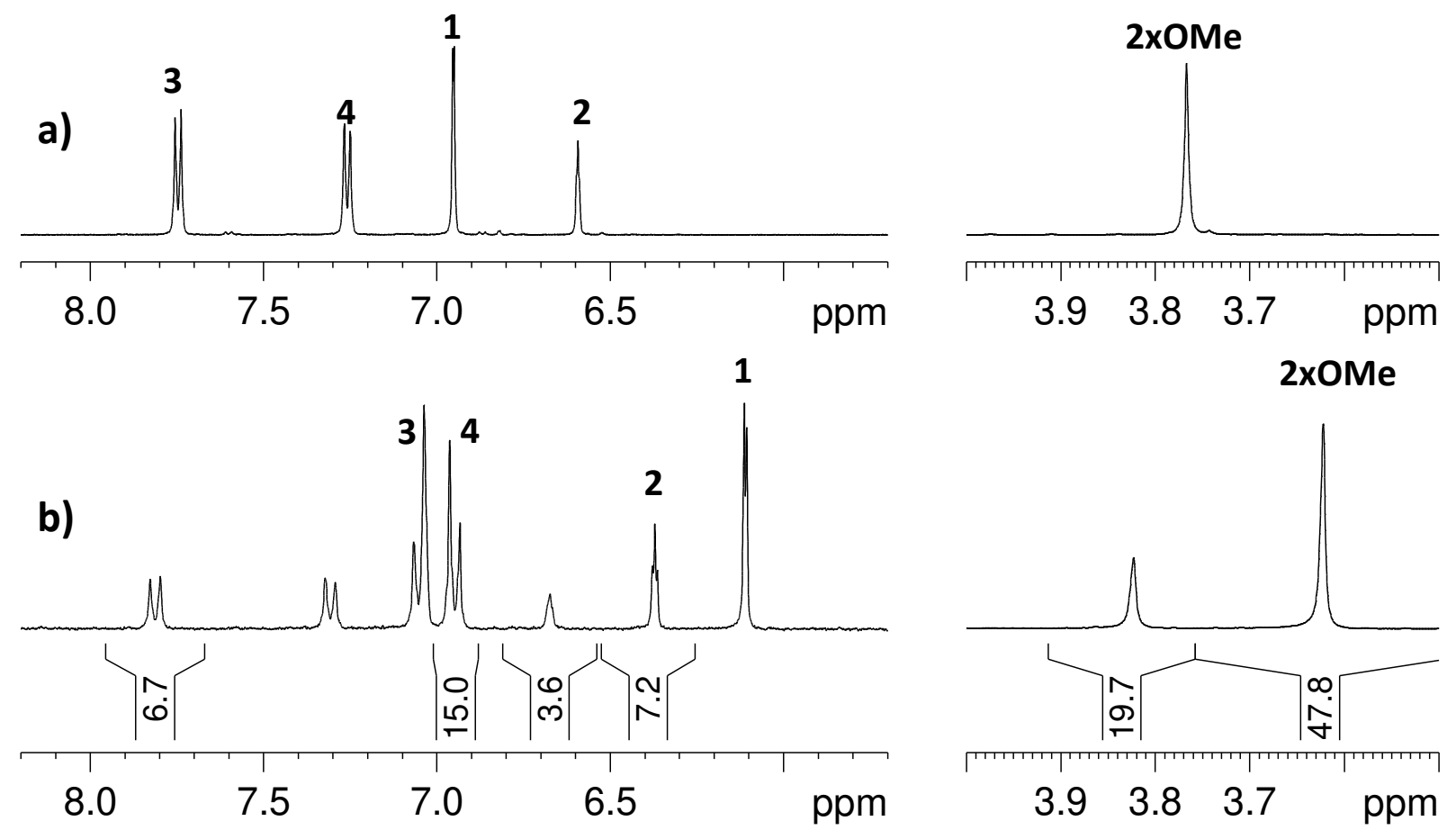

Figure 4. ${ }^{1} \mathrm{H}$ NMR spectra of 5 in $\mathrm{D}_{2} \mathrm{O}(\mathrm{pH}=2)$ at $22{ }^{\circ} \mathrm{C}$ a) before and $\left.\mathrm{b}\right)$ after irradiation with 365 nm light (PSS). 
Finally, as it clearly appeared that the thermal behavior of $\mathbf{5}$ in cis configuration is correlated to solvent acidity, the thermal response of the cis isomer of $\mathbf{4}$, having the structure the closest one to 5, was investigated after irradiation with $365 \mathrm{~nm}$ light, in the presence of phenylphosphonic acid (PPA) to mimic the effect of $\mathrm{PO}_{3} \mathrm{H}_{2}$ substituent. While in the absence of acid, the decay of the $\mathbf{4}$ cis isomer was mono-exponential, in the presence of acid, it became biexponential and was accelerated (Figure S27).

\subsection{Discussion}

From the set of experiments and data reported in Table 1, it is clear that the photoisomerization from trans to cis of the azoresveratrol derivatives 1-5 investigated is realized upon adequate light irradiation and the ratio between trans and cis isomers depends on temperature, solvent and substituents [5-6,10-14]. Substituents on the phenyl rings appear to strongly affect the thermal cis-to-trans relaxation rate. $\mathbf{1}$ and $\mathbf{2}$ present the lowest conversion ratio into the cis isomers ( 24 and $25 \%$, respectively) associated with the lowest thermal stability (4.1 and $3.0 \times 10^{-3} \mathrm{~s}^{-1}$, respectively), and these results were obtained at low temperature to slow the relaxation. Both have a hydroxy group in para position of one phenyl group. Experiments being conducted in polar acetonitrile containing non-negligible amount of water, one can expect intermolecular hydrogen bonds between the nitrogen atom and the solvent proton, as well as between the para-OH group and the water oxygen atom [26-27], which then favor a hydrazonelike electronic distribution with a single $\mathrm{N}-\mathrm{N}$ bond. The free rotation around the $\mathrm{N}-\mathrm{N}$ bond facilitates the recovery of the more stable trans isomer. Although the mechanism of isomerization has been debated (i.e. rotation, inversion, concerted inversion) $[9,28-30]$, an increase in dipole character (or resonance) lowers the activation barrier for thermal relaxation, 
accelerating the reversion from the cis to trans isomers. However, in the case of $\mathbf{3}$, having also a hydroxy group in its para-phenyl position, the trans-cis photoconversion and the thermal stability of the cis isomer at $-45^{\circ} \mathrm{C}$ are higher $\left(64 \%\right.$ and $\left.1.4 \times 10-4 \mathrm{~s}^{-1}\right)$ than results obtained with 1 and 2. Previous studies showed that azobenzenes carrying two or more ortho-substituents exhibit higher thermal stability compared to the unsubstituted azobenzene [10-12,31-33]. This "ortho-effect" is likely due to steric hindrance between the ortho-methyl groups and the lone pair electrons of nitrogen atoms, causing retardation in the cis-to-trans conversion [31]. In contrast, ortho-methoxy groups (6-7) have a completely opposite effect as no trace of the cis isomer could be detected, even at low temperature. In that case, the quinone-phenylhydrazone derivative was detected in solution, alone or in tautomeric equilibrium with the azo from, probably stabilized by some intramolecular interactions between $\mathrm{NH}$ and the oxygen atom of the methoxy group. Now, considering the azo derivatives $\mathbf{4}$ and $\mathbf{5}$ that are substituted by paramethoxy and para-phosphoric ester, respectively, their behavior can be compared with that of the derivative 2, having the hydroxy group in its para-phenyl position. A huge increase in the conversion ratio and thermal stability was observed as already reported with similar structures (para-hydroxy-azobenzene and para-alkoxy $\left(\mathrm{O}-\mathrm{C}_{6} \mathrm{H}_{11}\right)$ azobenzene) [34]. The authors justified the enhancement in the thermal stability of the cis isomer with alkoxy substituent by the fact that the thermal reversion cis-to-trans proceeded through an inversion mechanism while for hydroxy-azobenzene, it involved a rotation route. Also, we observed an increase of the thermal rates of relaxation cis-to-trans of $\mathbf{4}$ and $\mathbf{5}$ at low $\mathrm{pH}$. Such an effect where protonation at the azo moiety reduces the activation barrier and then accelerates the relaxation, has already been reported [35-42]. The most plausible explanation is to suggest an acid-base equilibrium between 
the non-protonated and protonated cis and trans isomers of 4+PPA and 5 (Scheme 2) [43]. At low $\mathrm{pH}$, two rate constants of relaxation were measured, the faster one being associated to the cis-to-trans isomerization of the protonated species because they are believed to be able to easily isomerize via the rotation about the $-\mathrm{N}=\mathrm{N}$ - bond due to a decrease in the double bond character.

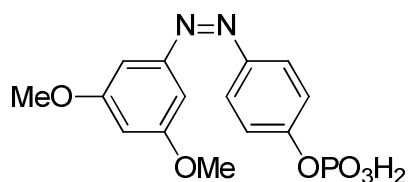

cis azo-isomer

$\mathrm{k}_{\Delta}$

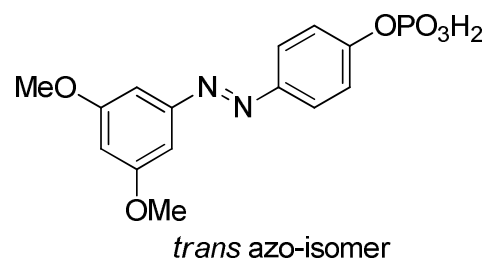

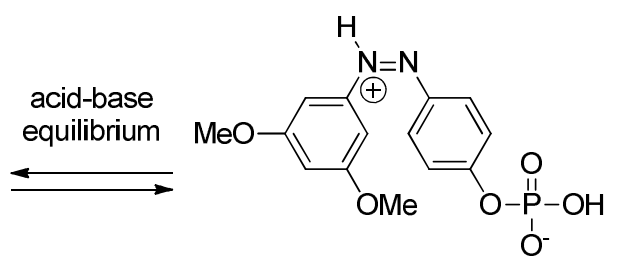

cis azo-isomer protonated
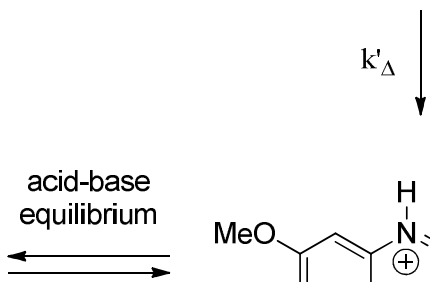

trans azo-isomer protonated

Scheme 2. Thermal relaxation pathways of the azo derivative 5 .

The geometries of $\mathbf{2}$ (azo and hydrazone derivatives in trans and cis configurations) and $\mathbf{4}$ (azo and protonated azo derivatives in trans and cis configurations) in their electronic ground state were optimized by DFT calculations at the $\omega \mathrm{B} 97 \mathrm{X}-\mathrm{D} / 6-311 \mathrm{G} *$ level (solvent $=$ acetonitrile) [44] allowing to determine geometric parameters and Mulliken charges (Tables S2 and S3). Representative bond lengths and Mulliken charges are gathered in Table 2. For $\mathbf{2}$ in the trans and cis configurations, the azo-to-hydrazone transformation mostly affects the N8C9 bond length and then the N7N8 one. This transformation is associated with a variation of the N8C9 
bond length by about 0.11-0.12 $\AA$ for both tautomers. The protonation of the derivative 4 also mostly affects the N8C9 bond length and then the N7N8 one. This protonation is associated with a variation of the N8C9 bond length by about $0.06-0.08 \AA$, and with a decrease of the COMe bond length by about $0.03 \AA$ and a concomitant increase of the O-Me bond length by about $0.01 \AA$. The N7N8 bond length is longer in the trans and cis quinone-phenyl hydrazone $\mathbf{2}$, then the bond order is much smaller, associated also with a substantial reduction of the bond length alternation (BLA). For the methoxy derivative 4, the same trends are observed although less pronounced, in agreement with the large difference observed experimentally about the thermal relaxation of the cis isomer. Upon protonation, $50 \%$ of the excess positive charge goes to the $\mathrm{NN}$ bridge and $50 \%$ to the methoxy-phenyl ring $\pi$-conjugated to the $\mathrm{N}=\mathrm{NH}^{+}$group. The para-methoxy substituent on the phenyl group in $\mathbf{4}$ works as a strong electron donor towards the protonated nitrogen atom (N7), leading to the hydrazone-type resonance structure in which the positive charge is delocalized on both nitrogen (N7) and oxygen atom in the methoxy group, then accelerating the rate of relaxation as observed experimentally when compared with the thermal evolution of $\mathbf{4}$ without PPA addition. This conclusion can also be applied to the derivative 5, with the phosphoric ester substituent playing itself the role of acid catalyst. We can then suggest that the thermal cis-to-trans isomerization of the para-hydroxy (1-3) and of the para-methoxy 4-protonated and para-phosphoric ester 5-protonated derivatives proceeds through a mechanism involving rotation of the $\mathrm{N}-\mathrm{N}$ bond. At neutral $\mathrm{pH}$ for the cis isomers $\mathbf{4}$ and 5, it is more difficult to conclude definitively but it seems reasonable to propose that the relaxation involves also the rotation of the $\mathrm{N}-\mathrm{N}$ bond. 
Table 2. Bond lengths ( $\AA$ ), Bond length alternation ${ }^{\mathrm{a}}$ and Mulliken charge (a.u.) distribution ${ }^{\mathrm{b}}$ on the representative fragments of the azo derivatives $\mathbf{2}$ (azo and hydrazone tautomers) and $\mathbf{4}$ (non-protonated and protonated) in their trans and cis configurations as determined at the

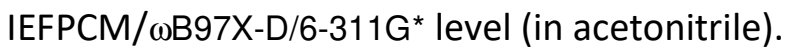

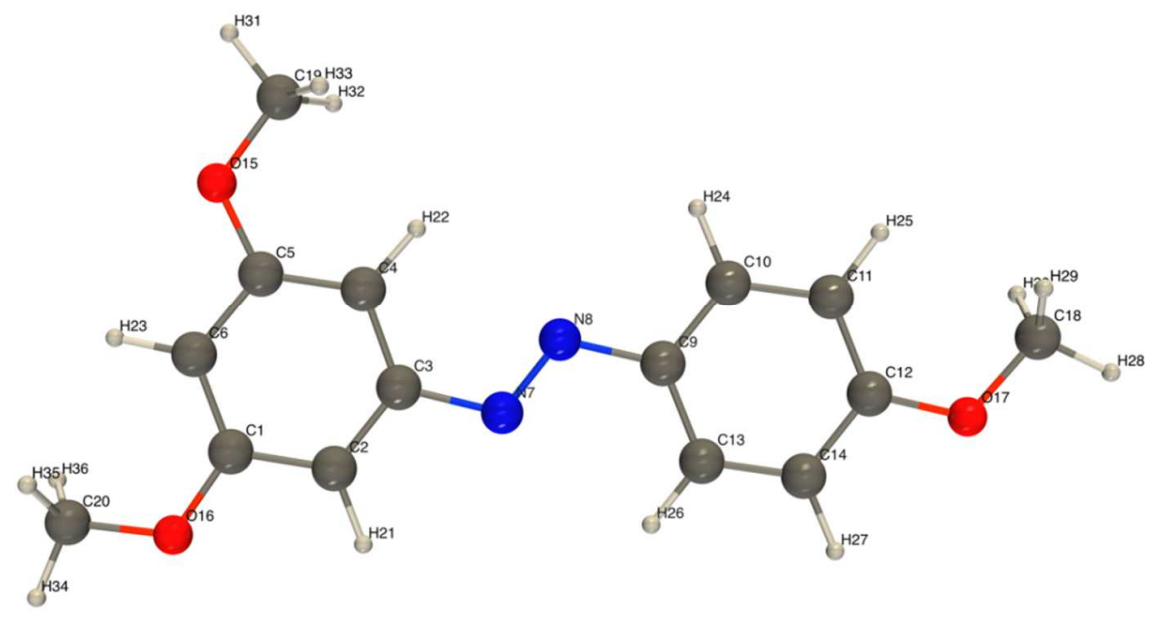

\begin{tabular}{ccccccccc}
\hline & 2-trans & 2-cis & 2-trans-Hydrazone & 2-cis-hydrazone & 4-trans & 4-cis & 4-trans $\mathrm{H}+$ & 4-cis $\mathrm{H}_{+}$ \\
$\mathrm{d}(\mathrm{C} 3 \mathrm{~N} 7)$ & 1.425 & 1.438 & 1.403 & 1.431 & 1.424 & 1.438 & 1.417 & 1.444 \\
$\mathrm{~d}(\mathrm{~N} 7 \mathrm{~N} 8)$ & 1.244 & 1.239 & 1.303 & 1.310 & 1.244 & 1.239 & 1.256 & 1.260 \\
$\mathrm{~d}(\mathrm{~N} 8 \mathrm{C} 9)$ & 1.414 & 1.433 & 1.308 & 1.310 & 1.413 & 1.433 & 1.357 & 1.354 \\
$\mathrm{~d}(\mathrm{C} 12-\mathrm{O} 17)$ & 1.350 & 1.353 & 1.227 & 1.228 & 1.347 & 1.350 & 1.320 & 1.318 \\
$\mathrm{~d}(\mathrm{O} 17-\mathrm{X})$ & 0.961 & 0.961 & - & - & 1.419 & 1.418 & 1.430 & 1.431 \\
$\mathrm{BLA}$ & 0.176 & 0.197 & 0.045 & 0.061 & 0.175 & 0.197 & 0.131 & 0.139 \\
& & & & & & & & \\
$\mathrm{q}(\mathrm{C} 3)$ & 0.13 & 0.02 & 0.40 & -0.17 & 0.13 & 0.02 & 0.38 & 0.07 \\
$\mathrm{q}(\mathrm{N} 7)$ & -0.23 & .017 & -0.15 & -0.10 & -0.23 & -0.17 & -0.01 & 0.06 \\
$\mathrm{q}(\mathrm{N} 2)$ & -0.21 & -0.18 & -0.18 & -0.17 & -0.21 & -0.18 & -0.12 & -0.10 \\
$\mathrm{q}(\mathrm{C} 9)$ & 0.10 & 0.01 & 0.17 & 0.11 & 0.10 & 0.01 & 0.16 & 0.11
\end{tabular}

${ }^{a} B L A=1 / 2(d(C 3 N 7)-2 \times d(N 7 N 8)+d(N 8-C 9)) ;{ }^{b} H$ charges were summed to their attached $\mathrm{C} / \mathrm{O} / \mathrm{N}$ atom. 


\section{Conclusion}

In conclusion, azoresveratrol and six of its derivatives were investigated to evidence their photochemical response as well as their behavior during thermal relaxation. When the phenyl group was para-substituted with $\mathrm{OH}$, the cis photoproduct was only detectable at low temperature showing a very fast relaxation (1 and $\mathbf{2}$ ) towards its trans isomer. Indeed, the $-\mathrm{N}=\mathrm{N}-$ $\pi$-bond is disrupted, due to the azo-hydrazone tautomeric equilibrium, followed by the rotation around the remaining $\sigma$-bond. The substitution of the phenyl groups with methyls in ortho position (3) resulted in slowing down the relaxation (factor 20 at $-45^{\circ} \mathrm{C}$ ). Inversely, the substitution with methoxy groups (6 and 7) shifted the equilibrium toward the hydrazone-type form and no cis isomer could be observed.

When $\mathrm{OH}$ was replaced with methoxy (4) or phosphoric ester (5) group, the cis isomer could be accumulated at ambient temperature since it was much more thermally stable. The thermal relaxation from the cis toward the trans isomers was accelerated by the acidic conditions associated with a bi-exponential decay. However, the corresponding rate constants at ambient temperature remained largely lower than those determined for hydroxy derivatives at low temperature.

Among all compounds studied, the phosphoric ester derivative $\mathbf{5}$ is the most promising one for biological applications. Indeed, it is water-soluble and could be photoconverted with $365 \mathrm{~nm}$ light producing a huge amount of the cis isomer (94\%), which is among the highest conversion reported today. It has a very good thermal stability and can be switched back photochemically with $436 \mathrm{~nm}$ light, although not completely. Its cycling performance is excellent as a very good reproducibility was observed upon successive cycles of 365/436 nm light irradiation. These 
promising properties pave the way to the future design of azoderivatives showing a full conversion in both directions upon distinct wavelengths of irradiation.

\section{Experimental section}

\subsection{General methods.}

Chemicals and solvents were obtained from commercial sources, and used without further purification unless otherwise noted. Reactions were monitored by TLC performed on MachereyNagel Alugram ${ }^{\circledR}$ Sil 60/UV254 sheets (thickness $0.2 \mathrm{~mm}$ ).

Purification of products was carried out by either column chromatography or thick layer chromatography. Column chromatography was carried out on using Macherey-Nagel silica gel (230-400 mesh). The purity of final compounds was verified by two types of high pressure liquid chromatography (HPLC) columns: $\mathrm{C}_{18}$ Interchim UPTISPHERE and $\mathrm{C}_{4}$ Interchim UPTISPHERE.

Analytical HPLC was performed on a Shimadzu LC-2010AHT system equipped with a UV detector set at $254 \mathrm{~nm}$ and $215 \mathrm{~nm}$. Compounds were dissolved in $50 \mu \mathrm{L}$ buffer B and $950 \mu \mathrm{L}$ buffer $\mathrm{A}$, and injected into the system. The following eluent systems were used: buffer $A\left(\mathrm{H}_{2} \mathrm{O} / \mathrm{TFA}\right.$, 100:0.1) and buffer $B\left(\mathrm{CH}_{3} \mathrm{CN} / \mathrm{H}_{2} \mathrm{O} / \mathrm{TFA}, 80: 20: 0.1\right)$. HPLC retention times ( $\mathrm{HPLC} \mathrm{t}_{\mathrm{R}}$ ) were obtained at a flow rate of $0.2 \mathrm{~mL} / \mathrm{min}$ for 35 min using the following conditions: a gradient run from $100 \%$ of buffer A over $1 \mathrm{~min}$, then to $100 \%$ of buffer B over the next $30 \mathrm{~min}$.

The melting point analyses were performed on a Stuart melting point SMP10 and are uncorrected.

Infrared spectra were performed on Bruker FT-IR spectrometer model $\alpha$.

Mass spectra were recorded on a Varian triple quadrupole $1200 \mathrm{~W}$ mass spectrometer equipped with a non-polar $\mathrm{C}_{18}$ TSK-gel Super ODS $(4.6 \times 50 \mathrm{~mm})$ column, using electrospray ionization and 
a UV detector (diode array). HRMS-ESI spectra were recorded on a Thermo Scientific Exactive spectrometer.

Preparative HPLC were performed using a Shimadzu semi-preparative HPLC system using an Apollo column $\mathrm{C}_{18} 250 \mathrm{~mm} \times 22 \mathrm{~mm}$ from Grace. Gradients used $\mathrm{CH}_{3} \mathrm{CN} / 0.1 \%$ trifluoroacetic acid and water/0.1\% trifluoroacetic acid at a flow rate of $6 \mathrm{~mL} / \mathrm{min}$.

NMR spectra were recorded on Bruker Neo-500 or Avance-300 spectrometers $\left({ }^{1} \mathrm{H}, 500 \mathrm{MHz}\right.$, ${ }^{13} \mathrm{C}, 125 \mathrm{MHz}$, or ${ }^{1} \mathrm{H}, 300 \mathrm{MHz},{ }^{13} \mathrm{C}, 75 \mathrm{MHz}$ ) equipped with TXI or QNP probe, using standard sequences. Data sets were processed using Bruker Topspin 4.0.2 software. Samples were dissolved in acetonitrile- $d_{3}$ or chloroform- $d_{1}$ or methanol- $d_{4}$ or water- $d_{2}$ in NMR glass tubes (5 $\mathrm{mm})$. Chemical shifts are expressed in ppm relative to residual proton signal in deuterated solvents. Chemical shifts are reported as position ( $\delta$ in ppm), multiplicity, coupling constant ( $\mathrm{in}$ $\mathrm{Hz}$ ), integral. The attributions of protons and carbons were achieved by analysis of 2D experiments (COSY, NOESY, HSQC and HMBC).

Photoirradiation was carried out directly into the NMR tube in a home-built apparatus. The emission spectrum of a 1000 Watt Xe-Hg high-pressure short-arc lamp (Newport), filtered by a band-pass glass filter (Lot QuantumDesign 011FG09 : $259<\lambda<388 \mathrm{~nm}$ with $\lambda_{\max }=330 \mathrm{~nm}$ and $\mathrm{T}=79 \%$ ) or a heating absorbing glass filter (Lot QuantumDesign KG1 : $300<\lambda<800 \mathrm{~nm}$ ) and interferential filter ( $\lambda=313 \mathrm{~nm}$ and $\mathrm{T}=17 \%, \lambda=365 \mathrm{~nm}$ and $\mathrm{T}=30 \%, \lambda=436 \mathrm{~nm}$ and $\mathrm{T}=50 \%)$ was focused on the end of a silica light-pipe (length $6 \mathrm{~cm}$, diameter $8 \mathrm{~mm}$ ), leading the light to the spinning sample tube, inserted in a quartz dewar. The temperature of the sample was controlled with a variable temperature unit (B-VT1000-Bruker, over a range of 123 to $423 \mathrm{~K}$ ). 
After irradiation, the NMR sample tube was rapidly transferred to the NMR probe where experiments were acquired.

To follow the time-evolution of concentrations, the NMR irradiated sample was kept in the spectrometer at controlled temperature and ${ }^{1} \mathrm{H}$ NMR spectra were recorded at regular time intervals for a long period. In each recorded spectrum, well-resolved signals characteristic of each compound were integrated and the sum was normalized to the value of $100 \%$ or to the initial value of concentration in $\mathrm{mol} \mathrm{L}^{-1}$ (mass balance respected).

UV/visible spectra were recorded on Cary50 spectrometer. Photoirradiation was carried out directly in the cuvette with a 200 Watt high-pressure Xe-Hg lamp equipped with the same filters as defined previously $(\lambda=313,365$ or $436 \mathrm{~nm})$.

\subsection{Synthesis.}

(E)-1-(3,5-dimethoxyphenyl)-2-(4-methoxyphenyl)diazene 4 [22]. To a solution of 2 (125 mg, $0.484 \mathrm{mmol})$ in acetone $(4.8 \mathrm{~mL})$ was added $\mathrm{K}_{2} \mathrm{CO}_{3}(200 \mathrm{mg}, 1.45 \mathrm{mmol})$ and Mel $(60.3 \mu \mathrm{L}, 0.968$ mmol). The mixture was stirred at room temperature overnight and monitored by TLC (Cyclohexane/EtOAc). The mixture was evaporated, dissolved in $\mathrm{CH}_{2} \mathrm{Cl}_{2}$, washed twice with water, dried over $\mathrm{MgSO}_{4}$, filtered and evaporated under vacuum. The residue was purified by flash chromatography (Cyclohexane/EtOAc, 0 to 30\%) to afford compound 4 as a brown solid (118 mg, 90\%). Mp: $115^{\circ} \mathrm{C} .{ }^{1} \mathrm{H}$ NMR (CD $\left.{ }_{3} \mathrm{OD}, 300 \mathrm{MHz}\right) \delta(p p m): 7.89$ (d, $\left.J=9.0 \mathrm{~Hz}, 2 x H-3\right), 7.08$ $(\mathrm{d}, J=9.0 \mathrm{~Hz}, 2 x \mathrm{H}-4), 7.06(\mathrm{~d}, J=2.2 \mathrm{~Hz}, 2 x \mathrm{H}-1), 6.60(\mathrm{t}, J=2.3 \mathrm{~Hz}, 1 \times \mathrm{H}-2), 3.89\left(\mathrm{~s}, 1 \mathrm{xCH}_{3}\right), 3.85$ (s, 2xCH 3 ). ${ }^{13} \mathrm{C}$ NMR $\left(\mathrm{CDCl}_{3}, 75 \mathrm{MHz}\right) \delta(\mathrm{ppm}): 162.5(\mathrm{Cq}), 161.3(2 \times \mathrm{Cq}), 154.5(\mathrm{Cq}), 146.6(\mathrm{Cq})$, 124.4 (2xCH), $114.0(2 \times C H), 102.5(1 \times C H), 100.2(2 \times C H), 54.7\left(1 x^{2} C_{3}\right), 54.6\left(2 x \mathrm{CH}_{3}\right)$. HRMS $\left.(\mathrm{ESI})^{+}\right)$ $[\mathrm{M}+\mathrm{H}]^{+}$Calcd for $\mathrm{C}_{15} \mathrm{H}_{17} \mathrm{~N}_{2} \mathrm{O}_{3}$ 273.12337; Found 273.12375. HPLC: $\mathrm{C}_{18}$ column: $\mathrm{t}_{\mathrm{R}}=34.3 \mathrm{~min}$, 
purity $97 \% . C_{4}$ column: $t_{R}=27.2 \mathrm{~min}$, purity $97 \%$. FTIR: $v\left(\mathrm{~cm}^{-1}\right): 3077,2993,2958,2834,1602$, $1582,1501,1455,1437,1305,1251,1149,1030,827$.

(E)-4-((3,5-dimethoxyphenyl)diazenyl)phenyl dihydrogen phosphate 5 [23]. To a solution of 2 (400 mg, $1.55 \mathrm{mmol})$ in $\mathrm{CH}_{2} \mathrm{Cl}_{2}\left(5.77 \mathrm{~mL}\right.$ ) using a $\mathrm{CaCl}_{2}$ guard tube was added $\mathrm{POCl}_{3}(0.577 \mathrm{~mL}$, $6.2 \mathrm{mmol})$ in $\mathrm{CH}_{2} \mathrm{Cl}_{2}(1.15 \mathrm{~mL})$ dropwise. The reaction mixture was stirred for $5 \mathrm{~min}$ at $10{ }^{\circ} \mathrm{C}$. $\mathrm{Et}_{3} \mathrm{~N}(0.431 \mathrm{~mL}, 3.1 \mathrm{mmol})$ in $\mathrm{CH}_{2} \mathrm{Cl}_{2}(1.15 \mathrm{~mL})$ was added dropwise to the mixture. The solution was stirred for $1 \mathrm{~h}$ at $10{ }^{\circ} \mathrm{C}$. Water $(10 \mathrm{~mL})$ was then added and the mixture was stirred for 30 minutes at $22{ }^{\circ} \mathrm{C}$. The $\mathrm{pH}$ of the reaction mixture was adjusted to c.a. 1 using $\mathrm{HCl}(1 \mathrm{M})$. The product was extracted twice with $\mathrm{CH}_{2} \mathrm{Cl}_{2}$. Combined organic layers were dried over $\mathrm{MgSO}_{4}$, filtered and evaporated under reduced pressure. The crude product was purified by semipreparative HPLC to afford compound $\mathbf{5}$ (180 mg, 34\%) as a brown-red powder. $\mathbf{M p}:>150^{\circ} \mathrm{C} .{ }^{1} \mathbf{H}$ NMR (CD $\left.{ }_{3} \mathrm{OD}, 300 \mathrm{MHz}\right) \delta(\mathrm{ppm}): 7.93(\mathrm{~d}, J=8.7 \mathrm{~Hz}, 2 \times \mathrm{H}-3), 7.38\left(\mathrm{dd}, J=8.9 \mathrm{~Hz},{ }^{4} J_{P-H}=1.0 \mathrm{~Hz}\right.$, $2 x \mathrm{H}-4), 7.10(\mathrm{~d}, J=2.3 \mathrm{~Hz}, 2 \times \mathrm{HH}-1), 6.63(\mathrm{t}, J=2.3 \mathrm{~Hz}, 1 \times \mathrm{H}-2), 3.86\left(\mathrm{~s}, 2 \times \mathrm{CH}_{3}\right) .{ }^{13} \mathrm{C}$ NMR $\left(\mathrm{CD}_{3} \mathrm{OD}, 75\right.$ $\mathrm{MHz}) \delta(\mathrm{ppm}): 161.3(2 \times \mathrm{Cq}), 154.3(\mathrm{Cq}), 153.8\left(\mathrm{~d},{ }^{2} \mathrm{~J}_{\mathrm{p}-\mathrm{C}}=6.6 \mathrm{~Hz}, \mathrm{Cq}\right), 149.1(\mathrm{Cq}), 123.9(2 \times \mathrm{CH})$, $120.5\left(\mathrm{~d},{ }^{3} \mathrm{P}_{\mathrm{P}-\mathrm{C}}=5.0 \mathrm{~Hz}, 2 \mathrm{xCH}\right), 103.1(1 \times \mathrm{CH}), 100.4(2 \times \mathrm{CH}), 54.6\left(2 \mathrm{xCH}_{3}\right)$. HRMS (ESI $)$ [M-H] ${ }^{-}$Calcd for $\mathrm{C}_{14} \mathrm{H}_{14} \mathrm{~N}_{2} \mathrm{O}_{6} \mathrm{P}$ 337.05840; Found 337.05588. HPLC: $\mathrm{C}_{18}$ column: $t_{R}=25.5$ min, purity $98 \%$. HPLC: $C_{4}$ column: $t_{R}=13.8$ min, purity $98 \% . F T I R: v\left(\mathrm{~cm}^{-1}\right): 3098,2944,2834,1591,1498,1427$, $1289,1208,1160,966,927,835$.

General procedure for the preparation of azo-compounds 3, 6 and 7. [21] To an ice-cold solution of aniline derivative ( 1 eq) in aqueous $1 \mathrm{M} \mathrm{HCl}\left(3\right.$ eq) and THF $(2.5 \mathrm{~mL} / \mathrm{mmol})$ at $0{ }^{\circ} \mathrm{C}$ was added $\mathrm{NaNO}_{2}(1.2 \mathrm{eq})$ dissolved in water $(2.5 \mathrm{~mL} / \mathrm{mmol})$ at $0{ }^{\circ} \mathrm{C}$. The mixture was stirred for $30 \mathrm{~min}$ at 0 ${ }^{\circ} \mathrm{C}$. An ice-cold solution of phenol derivative (1.2 eq.) in aqueous $1 \mathrm{M} \mathrm{NaOH}$ (3 eq) was added 
dropwise to the reaction mixture at $0-5{ }^{\circ} \mathrm{C}$. The mixture was stirred for $1 \mathrm{~h}$ at $0{ }^{\circ} \mathrm{C}$. THF was evaporated. The residue was taken in EtOAc and water, extracted twice with EtOAc. Combined organic layers were washed with aqueous sat. $\mathrm{NH}_{4} \mathrm{Cl}$, dried over $\mathrm{MgSO}_{4}$, filtered and evaporated under reduced pressure. The residue was purified by flash chromatography.

(E)-3-methyl-4-(o-tolyldiazenyl)phenol 3. According to the general procedure, compound $\mathbf{3}$ was purified by flash chromatography (Cyclohexane/EtOAc, 0 to 30\%) and obtained as a brown solid (118 mg, 90\%). Mp : $122^{\circ} \mathrm{C} .{ }^{1} \mathrm{H}$ NMR (CD $\left.3 \mathrm{OD}, 300 \mathrm{MHz}\right) \delta(\mathrm{ppm}): 7.63(\mathrm{~d}, J=8.8 \mathrm{~Hz}, 1 \mathrm{xH}-3), 7.56$ (dd, $J=7.4$ and $1.2 \mathrm{~Hz}, 1 \times \mathrm{HH}-4), 7.27(\mathrm{~m}, \mathrm{H}-5, \mathrm{H}-6, \mathrm{H}-7), 6.78(\mathrm{~d}, J=2.8 \mathrm{~Hz}, 1 \times \mathrm{H}-1), 6.69(\mathrm{dd}, J=8.8$ and $2.7 \mathrm{~Hz}, 1 \times \mathrm{HH}-2), 2.69\left(\mathrm{~s}, 2 \times \mathrm{CH}_{3}\right) .{ }^{13} \mathrm{C}$ NMR (CD $\left.3 \mathrm{OD}, 75 \mathrm{MHz}\right) \delta(\mathrm{ppm}): 160.3(\mathrm{Cq}), 151.1(\mathrm{Cq})$, $144.6(\mathrm{Cq}), 140.6(\mathrm{Cq}), 136.9(\mathrm{Cq}), 130.8(\mathrm{CH}), 129.5(\mathrm{CH}), 126.0(\mathrm{CH}), 117.0(\mathrm{CH}), 116.5(\mathrm{CH})$, $115.2(\mathrm{CH}), 113.3(\mathrm{CH}), 16.5\left(\mathrm{CH}_{3}\right), 16.3\left(\mathrm{CH}_{3}\right)$. HRMS (ESI) $[\mathrm{M}-\mathrm{H}]^{-}$Calcd for $\mathrm{C}_{14} \mathrm{H}_{15} \mathrm{~N}_{2} \mathrm{O}_{3}$ 225.10224; Found 225.10019. HPLC: $C_{18}$ column: $t_{R}=32.8$ min, purity $>99 \%$. HPLC: $C_{4}$ column: $t_{R}$ $=25.3 \mathrm{~min}$, purity $98 \%$ FTIR $: \mathrm{v}\left(\mathrm{cm}^{-1}\right): 3276,3019,2923,1591,1479,1455,1237,1152,1033$, $860,827,761$.

(E)-3-methoxy-4-((2-methoxyphenyl)diazenyl)phenol 6. According to the general procedure, compound 6 was purified by flash chromatography $\left(\mathrm{CH}_{2} \mathrm{Cl}_{2} / \mathrm{MeOH}, 0\right.$ to $\left.2 \%\right)$ and obtained as a brown solid (168 mg, 40\%). $\mathrm{Mp}:>170^{\circ} \mathrm{C} .{ }^{1} \mathrm{H}$ NMR $\left(\mathrm{CD}_{3} \mathrm{OD}, 300 \mathrm{MHz}\right) \delta(\mathrm{ppm})$ : (major form, azo derivative) $7.61(\mathrm{~d}, J=8.9 \mathrm{~Hz}, 1 \mathrm{xH}-5), 7.52(\mathrm{dd}, J=7.9 \mathrm{~Hz}$ and $1.2 \mathrm{~Hz}, 1 \mathrm{xH}-12), 7.40(\mathrm{t}, J=7.2 \mathrm{~Hz}$, $1 x H-10), 7.17(d, J=8.3 \mathrm{~Hz}, 1 \times \mathrm{HH}-9), 6.99(\mathrm{t}, J=7.6 \mathrm{~Hz}, 1 \times \mathrm{xH}-11), 6.59(\mathrm{~d}, J=2.1 \mathrm{~Hz}, 1 \mathrm{xH}-2), 6.43$ (dd, $J=8.8$ and $2.2 \mathrm{~Hz}, 1 \times \mathrm{H}-6), 3.99\left(\mathrm{~s}, 1 \times \mathrm{CH}_{3}\right), 3.96\left(\mathrm{~s}, 1 \mathrm{xCH}_{3}\right) ;{ }^{13} \mathrm{C}$ NMR $\left(\mathrm{CD}_{3} \mathrm{OD}, 75 \mathrm{MHz}\right)$ $\delta(p p m): 162.6(\mathrm{Cq}), 159.1(\mathrm{Cq}), 156.3(\mathrm{Cq}), 142.8(\mathrm{Cq}), 136.2(\mathrm{Cq}), 131.0(\mathrm{CH}), 120.4(\mathrm{CH}), 118.1$ (CH), $116.8(\mathrm{CH}), 112.6(\mathrm{CH}), 107.7(\mathrm{CH}), 99.4(\mathrm{CH}), 55.4\left(\mathrm{CH}_{3}\right), 55.2\left(\mathrm{CH}_{3}\right) .{ }^{1} \mathrm{H}$ NMR $\left(\mathrm{CD}_{3} \mathrm{OD}, 500\right.$ 
$\mathrm{MHz}) \delta(\mathrm{ppm})$ : (minor form, hydrazone derivative) 7.71 (dd, $J=8.0$ and $1.4 \mathrm{~Hz}, 1 \mathrm{xH}-12), 7.37$ (d, J $=9.9 \mathrm{~Hz}, 1 \times \mathrm{H}-5), 7.17(\mathrm{~m}, 1 \mathrm{xH}-10), 7.11(\mathrm{dd}, J=8.1$ and $1.0 \mathrm{~Hz}, 1 \times \mathrm{H}-9), 7.06(\mathrm{t}, J=7.6 \mathrm{~Hz}, 1 \mathrm{xH}-$ 11), $6.35(\mathrm{dd}, J=9.8$ and $1.8 \mathrm{~Hz}, 1 \times \mathrm{xH}-6), 6.06(\mathrm{~d}, J=1.8 \mathrm{~Hz}, 1 \times \mathrm{H}-2), 4.09\left(\mathrm{~s}, 1 \times \mathrm{xH}_{3}\right), 4.02(\mathrm{~s}$, 1xCH $\mathrm{CH}_{3}$. HRMS $\left(\mathrm{ESI}^{+}\right)[\mathrm{M}+\mathrm{H}]^{+}$Calcd for $\mathrm{C}_{14} \mathrm{H}_{13} \mathrm{~N}_{2} \mathrm{O}_{3}$ 259.10772; Found 259.10840. HPLC: $\mathrm{C}_{18}$ column: $t_{R}=26.9 \mathrm{~min}$, purity $>99 \%$. HPLC: $C_{4}$ column: $t_{R}=16.3 \mathrm{~min}$, purity $>99 \%$. FTIR $: v\left(\mathrm{~cm}^{-1}\right)$ : 3442, 2999, 2935, 2831, 1605, 1579, 1475, 1429, 1308, 1244, 1117, 1026, 832, 756.

3,5-dimethoxy-4-(2-(2-methoxyphenyl)hydrazone)cyclohexa-2,5-dienone 7. According to the general procedure, compound 7 was purified by flash chromatography $\left(\mathrm{CH}_{2} \mathrm{Cl}_{2} / \mathrm{MeOH}, 0\right.$ to $\left.5 \%\right)$ and obtained as a red-brown solid (407 mg, 87\%). Mp: $>220^{\circ} \mathrm{C} .{ }^{1} \mathbf{H}$ NMR $\left(\mathrm{CD}_{3} \mathrm{OD}, 300 \mathrm{MHz}\right)$ $\delta(\mathrm{ppm}): 7.68$ (dd, $J=7.9$ and $1.5 \mathrm{~Hz}, 1 \mathrm{x}-12), 7.09(\mathrm{~m}, \mathrm{H}-10, \mathrm{H}-9, \mathrm{H}-11), 5.81(\mathrm{~d}, J=1.8 \mathrm{~Hz}, 1 \mathrm{xH}-2)$, $5.77(\mathrm{~d}, J=1.9 \mathrm{~Hz}, 1 \times \mathrm{H}-6), 4.04\left(\mathrm{~s}, \mathrm{CH}_{3}\right), 4.00\left(\mathrm{~s}, \mathrm{CH}_{3}\right), 3.89\left(\mathrm{~s}, \mathrm{CH}_{3}\right) .{ }^{13} \mathrm{C}$ NMR $\left(\mathrm{CD}_{3} \mathrm{OD}, 75 \mathrm{MHz}\right)$ $\delta(p p m): 187.2(\mathrm{Cq}), 163.6(\mathrm{Cq}), 160.7(\mathrm{Cq}), 148.0(\mathrm{Cq}), 131.2(\mathrm{Cq}), 125.0(\mathrm{CH}), 121.9(\mathrm{CH}), 121.2$ $(\mathrm{CH}), 113.9(\mathrm{CH}), 110.8(\mathrm{CH}), 100.6(\mathrm{CH}), 99.8(\mathrm{CH}), 55.9\left(\mathrm{CH}_{3}\right), 55.4\left(\mathrm{CH}_{3}\right), 55.3\left(\mathrm{CH}_{3}\right)$. HRMS $\left(\mathrm{ESI}^{+}\right)[\mathrm{M}+\mathrm{H}]^{+}$Calcd for $\mathrm{C}_{15} \mathrm{H}_{17} \mathrm{~N}_{2} \mathrm{O}_{4}$ 289.11828; Found 289.11874. HPLC: $\mathrm{C}_{18}$ column: $\mathrm{t}_{\mathrm{R}}=27.9$ min, purity $96 \% . C_{4}$ column: $t_{R}=18.1$ min, purity $99 \%$. FTIR $: v\left(\mathrm{~cm}^{-1}\right): 3289,3053,2954,1626$, $1596,1523,1407,1264,1224,1123,767,818,772$.

\subsection{Crystallographic data}

Crystal structures of 1-3 were obtained. The crystals of small and poor quality were mounted on a Xcalibur equipped with monochromatized Mo-Ka radiation $(0.71073 \AA$ ). The data collection, unit cell refinement, and data reduction were performed using the CrysAlis CCD, Oxford Diffraction Ltd. software package [45]. The structural determination was carried out by direct 
methods, and the refinement of atomic parameters based on full-matrix least-squares on $F^{2}$ were performed using the SHELX-2014 program [46] within the WINGX package [47].

The positions of non-hydrogens atoms were determined and refinement by SHELX-2014 program. The positions of the hydrogen atoms were placed at calculated positions generated according to the stereochemistry and refined using a riding model in SHELX-2014.

Supplementary crystallographic data can be found in the CCDC deposit (CCDC 18973181897319-1897320), and obtained free of charge from the Cambridge Crystallographic Data Centre via www.ccdc.cam.ac.uk/data_request/cif/.

\subsection{DFT calculations}

The geometries of all compounds were fully optimized at the density functional theory level with the $\omega B 97 X-D$ exchange-correlation functional [44] and the 6-311G(d) atomic basis set. A TIGHT convergence threshold on the residual forces on the atoms $\left(1.5 \times 10^{-5}\right.$ Hartree/Bohr or Hartree/radian) was employed. Solvent (acetonitrile) effects were accounted for by using the integral equation formalism of the polarizable continuum model (IEFPCM) [48]. All calculations were performed using the Gaussian16 package [49]. The DrawMol program was used to generate all the figures [50].

\section{NOTES}

The authors declare no competing financial interest. JB and LA contributed equally.

\section{ACKNOWLEDGEMENTS}

The calculations were performed on the computing facilities of the Consortium des Équipements de Calcul Intensif (CÉCl, http://www.ceci-hpc.be ), and particularly those of the 
Technological Platform on High-Performance Computing located at UNamur (http://www.ptci.unamur.be ), for which the authors gratefully acknowledge the financial support of the FNRS-FRFC, of the Walloon Region, and of the University of Namur.

\section{Appendix A. Supplementary data}

The Supplementary data related to this article (Spectroscopic data, crystallographic data, UV/visible spectra and NMR spectra before and after irradiation, kinetics of thermal evolution, DFT results including atomic Cartesian coordinates of the optimized structures) can be found at http://dx.doi.org

\section{Appendix B. Supplementary crystallographic data}

CCDC 1897318-1897319-1897320 contain the supplementary crystallographic data for this paper. These data can be obtained free of charge via www.ccdc.cam.ac.uk/data_request/cif, or by emailing data_request@ccdc.cam.ac.uk, or by contacting The Cambridge Crystallographic Data Centre, 12 Union Road, Cambridge CB2 1EZ, UK; fax: +44 1223336033.

\section{References}

[1] Irie M, Fukaminato T, Matsuda K, Kobatake S. Photochromism of diarylethene molecules and crystals : memories, switches, and actuators. Chem Rev 2014;114:12174-277. https://pubs.acs.org/doi/10.1021/cr500249p. 
[2] Szymanski W, Beierle JM, Kistemaker HAV, Velema WA, Feringa BL. Reversible photocontrol of biological systems by the incorporation of molecular photoswitches. Chem Rev 2013;113: 6114-78. https://pubs.acs.org/doi/abs/10.1021/cr300179f.

[3] Beharry AA, Woolley GA. Azobenzene photoswitches for biomolecules. Chem Soc Rev 2011; 40:4422-37. https://pubs.acs.org/doi/10.1039/c1cS15023e.

[4] (a) Velema WA, Szymanski W, Feringa BL. Photopharmacology: beyond proof of principle. J Am Chem Soc 2014;136:2178-91. https://pubs.acs.org/doi/10.1021/ja413063e. (b) Lee BI, Suh YS, Chung YJ, Yu K, Park CB. Shedding Light on Alzheimer's $\beta$-Amyloidosis: Photosensitized Methylene Blue Inhibits Self-Assembly of $\beta$-Amyloid Peptides and Disintegrates Their Aggregates. Sci Reports 2017;7:1-10. https://doi.org/10.1038/s41598-017-07581-2.

[5] Hartley GS. The cis-form of azobenzene and the velocity of the thermal cis $\rightarrow$ trans conversion of azobenzene and some derivatives. J Chem Soc 1938;113:633-42. https://doi.org/10.1039/jr9380000633.

[6] Brode WR, Gould JH, Wyman GM. The Relation between the Absorption Spectra and the Chemical Constitution of Dyes. XXV. Phototropism and cis-trans Isomerism in Aromatic Azo Compounds. J Am Chem Soc 1952;74:4641-46. https://doi.org/10.1021/ja01138a059.

[7] Kojima M, Nebashi S, Ogawa K, Kurita N. Effect of solvent on cis-to-trans isomerization of 4hydroxyazobenzene aggregated through intermolecular hydrogen bonds. J Phys Org Chem 2005; 18:994-1000. https://doi.org/10.1002/poc.944.

[8] Kurita N, Nebashi S, Kojima M. Density functional molecular orbital calculations on the stability of hydrogen-bonded 4-hydroxyazobenzene dimers. Chem Phys Lett 2005;408:197-204. https://doi.org/10.1016/j.cplett.2005.04.047. 
[9] Dokic J, Gothe M, Wirth J, Peters MV, Schwarz J, Hecht S, Saalfrank P. Quantum Chemical Investigation of Thermal Cis-to-Trans Isomerization of Azobenzene Derivatives: Substituent Effects, Solvent Effects, and Comparison to Experimental Data. J Phys Chem A 2009;113:676373. https://doi.org/10.1021/jp9021344.

[10] Nishimura N.; Sueyoshi T.; Yamanaka H.; Imai E.; Yamamoto S.; Hasegawa S. Thermal Cis-toTrans Isomerization of Substituted Azobenzenes II. Substituent and Solvent Effects. Bull Chem Soc Jpn 1976;49:1381-7. https://doi.org/10.1246/bcsj.49.1381.

[11] Le Fevre RJW, Northcott J. The effects of substituents and solvents on the cis $\rightarrow$ trans change of azobenzene. J Chem Soc 1953:867-70. https://doi.org/ 10.1039/jr9530000867.

[12] Brode WR, Gould JH, Wyman GM. The Relation between the Absorption Spectra and the Chemical Constitution of Dyes. XXVI. Effect of Solvent and of Temperature on the cis-trans Isomerization of Azo Dyes. J Am Chem Soc. 1953;75:1856-9. https://doi.org/ 10.1021/ja01138a059.

[13] Birnbaum PP, Style DWG. The photo-isomerization of some azobenzene derivatives. Trans Faraday Soc 1954;50:1192-6. https://doi.org/10.1039/tf9545001192.

[14] Gabor G, Fischer E. Spectra and cis-trans isomerism in highly dipolar derivatives of azobenzene. J Phys Chem 1971;75:581-3. https://doi.org/ 10.1021/j100674a023.

[15] Dzeba I, Pedzinski T, Mihaljevi B. Photophysical and photochemical properties of

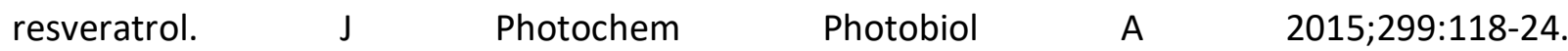
https://doi.org/10.1016/j.jphotochem.2014.11.019.

[16] Rivière C, Papastamoulis Y, Fortin P-Y, Delchier N, Andriamanarivo S, Waffo-Teguo P, Kapche GDWF, Amira-Guebalia H, Delaunay J-C, Mérillon J-M, Richard T, Monti J-P. New stilbene 
dimers against amyloid fibril formation. Bioorg Med Chem Lett 2010;20:3441-43. https://doi.org/10.1016/j.bmcl.2009.09.074.

[17] (a) Feng Y, Wanga X-P, Yang S-G; Wang Y-J, Zhang X, Du X-T, Sun X-X, Zhao M, Huang L, Liu R-T. Resveratrol inhibits beta-amyloid oligomeric cytotoxicity but does not prevent oligomer formation. NeuroToxicology 2009;30:986-95. https://doi.org/ 10.1016/j.neuro.2009.08.013. (b) Jia Y, Wang N, Liu X. Resveratrol and Amyloid-Beta: Mechanistic Insights. Nutrients 2017;9:112235. https://doi.org/ 10.3390/nu9101122. (c) Gautam S, Karmakar S, Batra R, Sharma P, Pradhan P, Singh J, Kundu B, Chowdhury PK. Polyphenols in combination with $\beta$-cyclodextrin can inhibit and disaggregate $\alpha$-synuclein amyloids under cell mimicking conditions: A promising therapeutic alternative. Biochim Biophys Acta Proteins Proteom 2017;1865:589-603. https://doi.org/ 10.1016/j.bbapap.2017.02.014. (d) Doig AJ, Derreumaux P. Inhibition of protein aggregation and amyloid formation by small molecules. Curr Op Struct Biol 2015;30:50-6. https://doi.org/ 10.1016/j.sbi.2014.12.004. (e) Ge J-F, Qiao J-P, Qi C-C, Wang C-W, Zhou J-N. The binding of resveratrol to monomer and fibril amyloid beta. Neurochem Intern 2012;61:1192-1201. https://doi.org/ 10.1016/j.neuint.2012.08.012. (f) Caruana M, Högen T, Levin J, Hillmer A, Giese A, Vassallo N. Inhibition and disaggregation of $\alpha$-synuclein oligomers by natural polyphenolic compounds. FEBS Lett 2011;585:1113-20. https://doi.org/10.1016/j.febslet.2011.03.046.

[18] (a) Mallory FB, Wood CS, Gordon JT. Photochemistry of Stilbenes. III. Some Aspects of the Mechanism of Photocyclization to Phenanthrenes. J Am Chem Soc 1964;86:3094-102. https://doi.org/10.1021/ja01069a025 (b) Francisco A, Boffi A, Villani L, D’Erme M, Macone A, Mosca L. Isolation and Identification of 2,4,6-Trihydroxyphenanthrene as a Byproduct of trans- 
Resveratrol Photochemical Isomerization and Electrocyclization. J Org Chem 2014;79:9381-84. https://doi.org/10.1021/jo501405m.

[19] Merino E. Synthesis of azobenzenes: the coloured pieces of molecular materials. Chem Soc Rev 2011;40:3835-53. https://doi.org/10.1039/c0cs00183j.

[20] Song YM, Ha YM, Kim JA, Chung KW, Uehara Y, Lee KJ, Chun P, Byun Y, Chung HY, Moon HR. Synthesis of novel azo-resveratrol azo-oxyresveratrol and their derivatives as potent tyrosinase inhibitors. Bioorg Med Chem 2012;22:7451-55. https://doi.org/10.1016/j.bmcl.2012.10.050.

[21] Eisel B, Hartrampf FWW, Meier T. Reversible optical control of F1 Fo -ATP synthase using photoswitchable inhibitors. FEBS Lett 2018;592:343-55. https://doi.org/10.1002/18733468.12958.

[22] Thorn-Seshold O, Borowiak M, Trauner D, Hasserodt J. Azoaryls as reversibly modulatable tubulin inhibitors. WO/2015/166295 2015.

[23] Zou $Y, X u T$, Huang $T$, Huang $X$, Liu J, Zhang X. A aryloxy phosphate preparation and application of ester list sodium salt. CN106146548 A 2016.

[24] Fisher E, Frei YF. Tautomerism and geometrical isomerism of arylazo-phenols and naphthols. Part I. 4-phenylazo-1-naphthol. J Chem Soc 1959;641:3159-63. https://doi.org/ $10.1039 / j r 9590003159$

[25] Haberfield P, Block PM, Lux MS. Enthalpies of solvent transfer of the transition states in the cis-trans isomerization of azo compounds. Rotation vs. the nitrogen inversion mechanism. J Am Chem Soc 1975;97:5804-6. https://doi.org/10.1021/ja00853a025 
[26] Garcia-Amoros J, Martinez M, Finkelmann H, Velasco D. Kinetico-mechanistic study of the thermal cis-to-trans isomerization of 4,4'-dialkoxyazoderivatives in nematic liquid crystals. J Phys Chem B 2010;114:1287-93. https://doi.org/10.1021/jp909557h

[27] Garcia-Amoros J, Sanchez-Ferrer A, Massad W.A, Nonell S, Velasco D. Kinetic study of the fast thermal cis-to-trans isomerisation of para- ortho- and polyhydroxyazobenzenes. Phys Chem Chem Phys 2010;12:13238-42. https://doi.org/10.1039/c004340k.

[28] Tiberio G, Muccioli L, Berardi R, Zannoni C. How does the trans-cis photoisomerization of azobenzene take place in organic solvents? Chem-PhysChem 2010;11:1018-28. https://doi.org/10.1002/cphc.200900652.

[29] Ootani Y, Satoh K, Nakayama A, Noro T, Taketsugu T. Ab initio molecular dynamics simulation of photoisomerization in azobenzene in the $n \mathrm{pi}^{*}$ state. J Chem Phys 2009;131:194306. https://doi.org/10.1063/1.3263918.

[30] Bandara HM, Friss TR, Enriquez MM, Isley W, Incarvito C, Frank HA, Gascon J, Burdette SC. Proof for the concerted inversion mechanism in the trans $\rightarrow$ cis isomerization of azobenzene using hydrogen bonding to induce isomer locking. J Org Chem 2010;75:4817-27. https://doi.org/10.1021/jo100866m.

[31] Nishioka $H$, Liang $X$, Asanuma $H$. Effect of the ortho modification of azobenzene on the photoregulatory efficiency of DNA hybridization and the thermal stability of its cis form. Chem Eur J 2010;16:2054-62. https://doi.org/10.1002/chem.200902789.

[32] Beharry AA, Sadovski O, Woolley GA. Azobenzene photoswitching without ultraviolet light. J Am Chem Soc 2011;133:19684-7. https://doi.org/10.1021/ja209239m. 
[33] Lin W-C, Tsai MC, Rajappa R, Kramer RH. Design of a Highly Bistable Photoswitchable Tethered Ligand for Rapid and Sustained Manipulation of Neurotransmission. J Am Chem Soc 2018;140:7445-8. https://doi.org/10.1021/jacs.8b03942.

[34] Garcia-Amoros J, Stopa G, Stochel G, van Eldik R, Martinez M, Velasco D. Activation volumes for cis-to-trans isomerisation reactions of azophenols: a clear mechanistic indicator? Phys Chem Chem Phys 2018;20:1286-92. https://doi.org/10.1039/C7CP07349F.

[35] Knoll H. Photoisomerism of azobenzenes. In: ed. W. Horspool X, Lenci F, editors. CRC Handbook of organic photochemistry and photobiology, Boca Raton: CRC Press; 2004;89: p. 189.

[36] Dunn N J, Humphries WH, Offenbacher AR, King TL, Gray JA. pH-Dependent cis $\rightarrow$ trans isomerization rates for azobenzene dyes in aqueous solution. J Phys Chem A 2009;113:13144151. https://doi.org/10.1021/jp903102u.

[37] Sawicki E. Physical Properties of the Aminoazobenzene Dyes. IV. The Position of Proton Addition. J Org Chem 1957;22:365-7. https://doi.org/10.1021/j001112a002.

[38] Bandara DHM, Burdette SC. Photoisomerization in different classes of azobenzene. Chem Soc Rev 2012;41:1809-25. https://doi.org/10.1039/c1cs15179g.

[39] Ciccone S, Halpern J. Catalysis of the cis-trans isomerization of azobenzene by acids and cupric salts. Can J Chem 1959;37:1903-10. https://doi.org/10.1139/v59-278.

[40] Buncel E, Lawton BT. The Wallach rearrangement Part II. Kinetics and mechanism of the acid-catalyzed rearrangement of azoxybenzene. Can J Chem 1965;43:862-75. https://doi.org/10.1139/v65-113. 
[41] Ochi R, Perur N, Yoshida K, Tamaoki N. Fast thermal cis-trans isomerization depending on $\mathrm{pH}$ and metal ions of water-soluble azobenzene derivatives containing a phosphate group. Tetrahedron 2015;71:3500-6. https://doi.org/10.1016/j.tet.2015.03.054.

[42] Matazo DRC, Ando RA, Borin AC, Santos PS. Azo-hydrazone tautomerism in protonated aminoazobenzenes: resonance Raman spectroscopy and quantum-chemical calculations. J Phys Chem A 2008;112:4437-43. https://doi.org/10.1021/jp800217c.

[43] Sanchez AM, Barra M, de Rossi RH. On the Mechanism of the Acid/Base-Catalyzed Thermal Cis-Trans Isomerization of Methyl Orange. J Org Chem 1999;64:1604-9. https://doi.org/10.1021/jo982069j.

[44] Chai JD, Head-Gordon M. Long-range corrected hybrid density functionals with damped atom-atom dispersion corrections. Phys Chem Chem Phys 2008;10:6615-20. https://doi.org/ 10.1039/b810189b.

[45] CrysAlis CCD Oxford Diffraction Ltd. Version 1.171.33.46

[46] Sheldrick GM. Programs for Crystal Structure Analysis; University of Göttingen: Göttingen Germany 2014.

[47] Farrugia LJ. WinGX and ORTEP for Windows: an update. J Appl Cryst 2012;45:849-54. https://doi.org/10.1107/S0021889812029111.

[48] Tomasi J, Mennucci B, Cammi R. Quantum Mechanical Continuum Solvation Models. Chem Rev 2005;105:2999-3094. https://doi.org/10.1021/cr9904009.

[49] Frisch M. J, Trucks G. W, Schlegel H. B, Scuseria G. E, Robb M. A, Cheeseman J. R, Scalmani G, Barone V, Mennucci B, Petersson G. A. et al. Gaussian 16 Revision A03; Gaussian Inc.: Wallingford CT 2016. 
[50] Liégeois V. DrawMol a graphical interface to visualize and build molecular structures UNamur http://unamur.be/drawmol.

\section{Highlights}

Photoswitching of azoresveratrol and six derivatives was studied by UV-Visible and NMR spectroscopies

Bi-exponential behaviour of the thermal relaxation was evidenced

DFT calculations were carried out to rationalize the experimental observations

Azo derivative with phosphoric ester substituent is water-soluble and shows a huge photoconversion to the cis isomer which has a very good thermal stability 